\title{
Keefektivan Konseling Kelompok Teknik Spirituality Cognitive Restructuring untuk Meningkatkan Self Esteem Siswa
}

\section{Dwi Bhakti Indri M. Faith}

KORESPONDEN PENULIS:

Dwi Bhakti Indri M. Faith Institut Pesantren $\mathrm{KH}$. Abdul Chalim Jalan Raya Tirtowening 17, Bendunganjati, Pacet,

Mojokerto, Jawa Timur, Indonesia Email:

dwibhaktiindrimfaith@yahoo.co.id

Halaman

$117-123$

\begin{abstract}
ABSTRAK
This study aimed to test the effectiveness of group counseling with spiritualitycognitive restructuring technique to improve students' self esteem. This was an experimental study with pretest-posttest control group design. There were two groups assigned through purposive sampling based on the result of pre-test conducted by the researcher. The data analysis technique of this study was Wilcoxon Signedrank-test. The result of Wilcoxon test showed that asymp.sig (2-tailed) was 0.026 $<0.05$, so $H_{a}$ was accepted and $H_{o}$ was rejected on the experimental group. In other words, group counseling with spirituality-cognitive restructuring technique was effective to Improve Students' self esteem. This study could be a guideline for the counselor in implementing Group counseling with spirituality-cognitive restructuring technique to improve the students' self esteem. The future researcher is expected to be able to implement this integrative approach in a broader area. Keywords: group counseling, spirituality cognitive restructuring, self esteem
\end{abstract}

\section{ABSTRACT}

Studi bertujuan untuk menguji keefektivan konseling kelompok teknik spirituality-cognitive restructuring untuk meningkatkan self esteem siswa. Studi menggunakan jenis penelitian eksperimen pretest-posttest control group design. Pada desain ini terdapat dua kelompok yaitu kelompok eksperimen (enam subjek) dan kelompok kontrol (enam subjek) yang dipilih melalui teknik purposive sample berdasarkan hasil pre-test yang telah dilakukan oleh peneliti. Instrumen pengumpulan data menggunakan skala self esteem. Teknik analisis data yang digunakan uji rank bertanda Wilcoxon. Hasil uji Wilcoxon menunjukkan bahwa asymp.sig (2-tailed) sebesar 0,026 <0,05, maka Ha diterima dan Ho ditolak pada kelompok eksperimen. Dapat dimaknai bahwa kelompok eksperimen dengan teknik spirituality-cognitive restructuring mampu meningkatkan self esteem siswa, dan hal yang 
berbeda ditunjukkan oleh kelompok kontrol. Studi ini dapat dijadikan pedoman guru BK dalam mengimplementasikan konseling kelompok dengan teknik spirituality-cognitive restructuring untuk meningkatkan self esteem siswa, dan peneliti selanjutnya diharapkan untuk dapat mengimplementasikan pendekatan integrasi ini pada wilayah yang lebih luas.

Kata kunci: konseling kelompok, spirituality cognitive restructuring, self esteem

\section{PENDAHULUAN}

Proses pembentukan identitas diri memiliki kaitan erat dengan bagaimana remaja menilai atau mengevaluasi diri karena perkembangan self esteem pada remaja, yang menentukan masa depannya (Santrock, 2007). Proses perkembangan self esteem ini berbeda-beda pada tiap individu (Aunilah, 2015; Basaran, 2016). Jika self esteem ini berkembang dengan optimal, maka dapat mengarahkan individu pada konstruk psikologis yang baik dan sebaliknya.

Berdasarkan penelitian yang dilakukan Jean Clore dan Scott Gaynor (2006), dapat diketahui bahwa 73\% mahasiswa perempuan yang berumur 21 tahun di U.S. University dilaporkan memiliki distress, self esteem yang rendah, dan gejala depresi. Selain itu, penelitian yang dilakukan Yusuf dan Bagus (2012) dengan sasaran siswa perempuan di SMA Negeri 15 Semarang menyatakan bahwa terdapat 113 responden memiliki self esteem yang tinggi, sedangkan 57 responden memiliki self esteem yang rendah. Hal ini membuktikan bahwa masa remaja mengalami pembentukan self esteem.

Berdasarkan hasil wawancara kepada guru bimbingan dan konseling di SMA Negeri 1 Semarang, SMA Negeri 6 Semarang, dan SMA Negeri 14 Semarang menyatakan bahwa terdapat siswa yang kurang percaya untuk mencapai cita-citanya, ragu-ragu dalam beropini di kelas, cenderung menarik diri dari lingkungan sosial. Selain itu, mereka kurang memiliki cara yang jelas dalam merencanakan keberhasilannya, memiliki konflik dengan temannya, dan cenderung pesimis. Ada beberapa aspek penyebab sikap dan perilaku tersebut, yaitu lingkungan dan kondisi keluarga yang pecah. Beberapa permasalahan yang telah dipaparkan menunjukkan bahwa masih terdapat siswa yang memiliki self esteem rendah.
Self esteem memiliki arti "penghormatan untuk diri" (Srivastava \& Joshi, 2014). Branden (Srivastava \& Joshi, 2014) menyatakan bahwa self esteem adalah disposisi untuk mengalami diri sebagai individu yang kompeten untuk mengatasi tantangan dasar kehidupan dan pantas mencapai kebahagiaan. Self esteem berhubungan dengan kesulitan emosi, depresi dan keputusasaan (Fanaj dkk., 2015). Self esteem berhubungan dengan depresi, kecemasan, kesulitan emosi, motivasi dan kepuasan umum dengan satu hidup (Srivastava \& Joshi, 2014). Pada beberapa remaja, self esteem rendah dapat berkembang menjadi masalah (Santrock, 2007). Pada sebuah studi dilakukan baru-baru ini, tingginya narsisme, rendahnya empati, dan kepekaan terhadap penolakan, bersama-sama dengan self esteem yang rendah, berkaitan dengan pikiranpikiran bengis pada remaja (Santrock, 2007).

Merujuk dari pernyataan Usher (Santrock, 2007), maka diperlukan suatu upaya untuk mengembangkan self esteem pada siswa. Upaya tersebut dapat dilakukan melalui layanan bimbingan dan konseling di sekolah. Layanan bimbingan dan konseling yang diintegrasikan dalam spiritualitas diharapkan mampu mendukung pengembangan pribadi dan membantu mengentaskan permasalahan siswa. Salah satu upaya untuk membantu mengentaskan permasalahan siswa dapat dilakukan dengan pemberian layanan konseling kelompok (Khasanah, 2014).

Studi ini bertujuan untuk mengetahui keefektifan konseling kelompok dengan teknik spirituality cognitive restructuring dalam meningkatkan self esteem siswa SMA Negeri di Kota Semarang. Hasil studi ini dapat dijadikan sebagai alternatif teknik konseling kelompok teknikspirituality cognitive restructuring untuk meningkatkan self esteem siswa.

\section{METODE PENELITIAN}

Studi ini menggunakan pendekatan kuantitatif dengan jenis eksperimen dan desain pretest posttest control group. Pada desain ini terdapat dua kelompok yaitu kelompok eksperimen (enam subjek) dan kelompok kontrol (enam subjek) yang dipilih melalui teknik purposive sampling. Instrumen pengumpulan data menggunakan skala selfesteem. Teknik analisis data yang digunakan Uji Rank Bertanda Wilcoxon. 


\section{HASIL DAN PEMBAHASAN}

Berdasarkan hasil kajian empirik pada studi pendahuluan dan need assesment, terdapat beberapa hasil penelitian. Konseling kelompok telah dilaksanakan di SMA Negeri Kota Semarang. Namun, teknik yang digunakan adalah teknik yang masih konvensional. Dalam arti, pemberian nasehat masih menjadi dominasi dalam proses konseling kelompok. Terdapat beberapa hambatan yang ditemukan dalam proses konseling kelompok, diantaranya perspektif awal tentang bimbingan dan konseling yang dimiliki siswa, perbandingan jumlah guru BK dengan siswa tidak seimbang, dan waktu pelaksanaan konseling kelompok yang biasanya dilakukan setelah pulang sekolah.

Konseling kelompok dengan integrasi spirituality ke dalam teknik cognitive restructuring belum pernah dilaksanakan di SMA Negeri di Kota Semarang. Pelaksanaan layanan konseling kelompok cenderung kurang memiliki persiapan yang matang. Persiapan cenderung dilakukan hanya berselang sehari atau tidak jarang dilakukan beberapa menit setelah melakukan keputusan untuk melakukan intervensi pada yang bersangkutan. Terdapat 19,59\% atau 87 siswa terindikasi memiliki self esteem yang rendah dan 68,47\% atau 304 siswa terindikasi memiliki self esteem yang sedang. Namun, hanya 11,94\% atau 54 siswa yang memiliki self esteem yang optimal berdasarkan hasil analisis CSEI (Coopersmith self esteem Inventory atau Inventori Harga Diri Coopersmith).

Self esteem dianggap sebagai persepsi tentang bagaimana individu mengevaluasi diri dan kompetensinya. Evaluasi yang dimaksud adalah positif atau negatif. Memiliki arti diri positif atau self esteem yang baik terkait dengan banyak perilaku positif, seperti prestasi, inisiasi, motivasi, dan kesehatan mental yang baik, begitu pula sebaliknya (Leong, 2008). Self esteem mengacu pada seseorang secara keseluruhan evaluasi positif atau negatif dari diri sendiri dan dapat dilihat dalam berbagai cara, sebagai sifat abadi, stabil dibandingkan rapuh, sebagai domain spesifik kontingen diri, atau sebagai tujuan itu seseorang (Srivastava \& Joshi, 2014).

Self esteem adalah kepuasan pada diri sendiri. Istilah harga diri berasal dari kata Yunani yang berarti "penghormatan untuk diri" (Srivastava \& Joshi, 2014). Menurut Branden (Srivastava \& Joshi, 2014) menyatakan bahwa self esteem adalah disposisi untuk mengalami diri sebagai individu yang kompeten untuk mengatasi tantangan dasar kehidupan dan pantas mencapai kebahagiaan. Self esteem dapat didefinisikan sebagai sikap individu pada dirinya, yang melibatkan evaluasi diri terkait dimensi positif dan negatif (dalam Srivastava \& Joshi, 2014). Coopersmith (1967) menyatakan bahwa self esteem adalah evaluasi yang dibuat dan kebiasaan dalam memandang dirinya, terutama mengenai sikap menerima dan menolak, dan merupakan indikasi dari besarnya kepercayaan terhadap kemampuan, keberartian, kesuksesan, dan keberhargaan.

Self esteem mencerminkan pemeliharaan sukses dari keyakinan dan memiliki fungsi dasar dari pendorong kecemasan (Salkind, 2006). Dalam hal ini, jika self esteem yang berkembang adalah self esteem yang positif, kesuksesan akan dapat diraih oleh individu dengan kecemasan yang sesuai dengan kadarnya. Namun, jika self esteem yang berkembang adalah self esteem yang cenderung negatif, kecemasan yang berkembang melebihi kadar yang seharusnya sehingga kesuksesan sulit diraih. Selain itu, self esteem memiliki peran yang cukup besar dalam hal percintaan, pekerjaan, dan kekuatan dalam merasakan kebahagiaan. Secara singkat, self esteem adalah penilaian pribadi mengenai keberhargaan dan keberartian yang ditunjukkan melalui sikap individu terhadap dirinya.

Low self esteem pada masa remaja memiliki resiko yang negatif pada domain terpenting dalam keseluruhan kehidupan (Erol, 2011). Berdasarkan penelitian ditemukan bahwa self esteem yang rendah memprediksi perilaku antisosial, gangguan makan, depresi, dan keinginan bunuh diri (Erol, 2011). Pernyataan ini diperkuat pula Fenzel (Santrock, 2007), menyatakan bahwa self esteem yang rendah dapat mengakibatkan depresi, bunuh diri, anoreksia nervosa, kenakalan remaja, dan masalah-masalah penyesuaian diri lainnya.

Low self esteem yang diindikasi telah terjadi pada siswa SMA Negeri 1 Semarang, SMA Negeri 6 Semarang, dan SMA Negeri 14 Semarang cenderung disebabkan karena proses kognitif yang kurang tepat. Terkait hal tersebut, konseling adalah salah satu pemberian bantuan yang tepat. Hal ini memiliki makna hubungan antara konselor dan konseli pada proses konseling, merupakan hubungan pemberian bantuan yang bersifat profesional dan memiliki 
keunikan tersendiri. Profesional dalam hal ini karena didasarkan pada pengetahuan yang khas, menerapkan suatu teknik intelektual dalam suatu pertemuan khusus dengan konseli agar konseli tersebut dapat lebih efektif menghadapi masalah, dan pertentangan-pertentangan atau konflik yang terjadi dalam dirinya.

Kadang kala seseorang kesulitan mengemukakan masalahnya secara individu atau membutuhkan orang lain (Puswanti, 2014). Gladding (2012) menggambarkan kelompok sebagai dua atau beberapa orang yang saling berinteraksi untuk mencapai tujuan demi keuntungan bersama. Wibowo (2005) menyebutkan tujuan konseling kelompok adalah individu akan mampu meningkatkan kemampuan untuk mengembangkan pribadi, mengatasi masalahmasalah pribadi, terampil dalam mengambil alternatif untuk memecahkan masalahnya, serta memberikan kemudahan dalam pertumbuhan dan perkembangan individu untuk melakukan tindakan yang selaras dengan kemampuaannya semaksimal mungkin melalui perilaku perwujudan diri.

Corey (2012) menyebutkan beberapa karakteristik yang harus menjadi bagian dari kepribadian seorang pemimpin kelompok (PK), yaitu: (1) kehadiran; (2) daya kekuatan pribadi; (3) keberanian; (4) kesediaan untuk menghadapi diri sendiri; (5) ketulusan dan keaslian; (6) rasa identitas; (7) percaya pada proses dan antusiasme kelompok; dan (8) daya cipta dan kreativitas. Selain itu, seorang konselor yang baik harus membekali diri dengan berbagai keterampilan konseling. Pada pelaksanaan konseling kelompok, ada beberapa keterampilan dasar yang harus dimiliki oleh pemimpin kelompok. Keterampilan dasar yang harus dimiliki konselor dalam layanan konseling kelompok, yaitu: (1) active listening (mendengar aktif); (2) refleksi; (3) klarifikasi dan bertanya; (4) meringkas; (5) menghubungkan (linking); (6) ceramah singkat dan pemberian informasi; (7) mendorong dan pendukung; (8) pengaturan nada; (9) pemodelan dan self-disclosure; (10) penggunaan mata; (11) penggunaan suara; (12) penggunaan energi pimpinan; (13) mengidentifikasi pengikut; (14) pemahaman multicultural; (15) focusing.

Spirituality sama dengan ruh atau pikiran di mana merupakan aspek alami manusia yang berbeda karena tidak tampak atau dapat diraba. Spirituality sebagai proses pencarian individu tentang makna dan keyakinan pada kekuatan yang lebih tinggi daripada diri sendiri. Menurut Harry Moody (Plumb, 2011), spirituality dapat disamakan dengan pengalaman di mana: (a) bergerak menjauh dari dunia luar dan menuju pada kehidupan jiwa yang terdalam; (b) dorongan untuk menyederhanakan permasalahan dalam kehidupan; (c) meningkatkan komitmen untuk berbudi luhur, seperti baik hati, kemurahan hati, cinta dan sebagainya; (d) meningkatkan level kesadaran ke level transedental yang lebih tinggi di mana dapat membentuk "bangunan" baru dan kemampuan yang luar biasa; dan (e) menyusun tujuan untuk memberikan balikan pada dunia tentang apa yang mereka dapatkan melalui spirituality dan untuk mengabdikan diri mereka pada sesama.

Spirituality seringkali dipersamakan dengan agama. Namun, seharusnya ada pembeda di antara keduanya. Spirituality didefinisikan sebagai pengalaman manusia menemukan makna, tujuan, dan nilai-nilai, yang mungkin atau tidak mungkin, termasuk konsep Tuhan atau makhluk transenden (Plumb, 2011: 7).

Agama didefinisikan sebagai kelembagaan formal untuk keyakinan dan praktik spiritual (Plumb, 2011). Spirituality sering dilihat dari segi pengalaman pribadi individu mencari suci dalam hidup dan berjuang untuk terhubung dengan Tuhan (Hamdan, 2008). Pengalaman ini mungkin atau tidak mungkin terkait dengan berbagai organisasi keagamaan (Thoreson \& Harris dalam Hamdan, 2008). Jika dianalogikan, spiritualitas merupakan air, yang mengandung keyakinan pada suatu perihal, dan agama merupakan wadah air, yang mengarahkan dan membentuk air. Terdapat tiga komponen dari spirituality, menurut Elkins dkk. (Lines, 2006), adalah 'makna dan tujuan hidup', 'misi dalam hidup' dan 'altruisme', dan hubungan antara keyakinan agama dan tanggung jawab sosial ditekankan dalam agama Yahudi, Kristen dan Islam, terutama jika iman yang matang dan intrinsik (Allport dan Ross dalam Lines, 2006).

Keefektifan konseling kelompok dengan teknik spirituality-cognitive restructuring untuk meningkatkan self esteem siswa dapat dilihat dari perbandingan antara tingkat self esteem siswa sebelum diberikan layanan konseling kelompok (skor pre-test) dan sesudah diberikan layanan konseling kelompok (skor post-test). Berikut adalah perbandingan skor pre-test dan post-test dapat disajikan pada Gambar 1. 


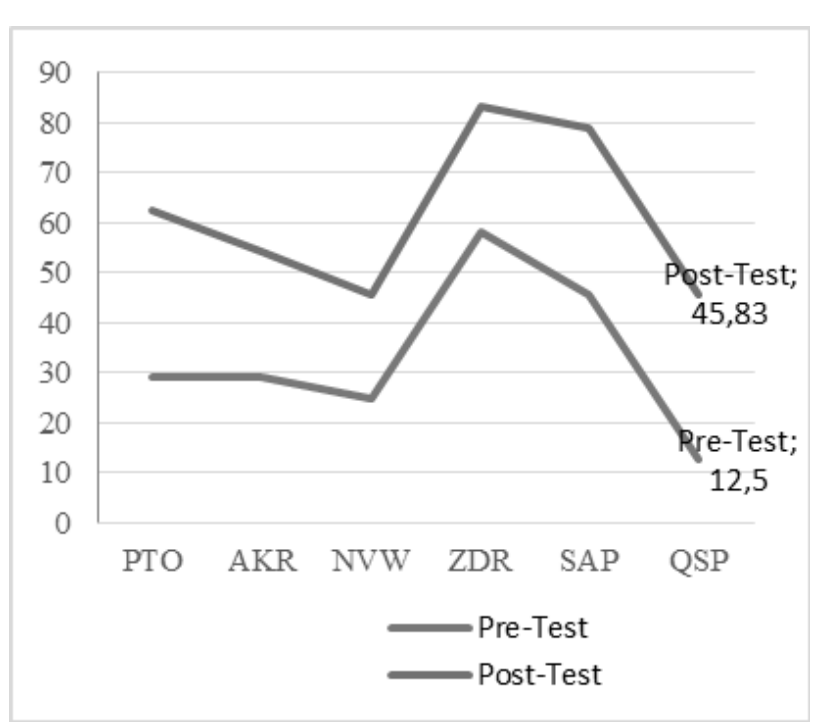

\section{Gambar 1 \\ Perbandingan Skor Pre-Test dan Post-Test Siswa secara}

Selanjutnya, terdapat hasil uji wilcoxon kelompok eksperimen dan kontrol. Hasil uji wilcoxon pada kelompok eksperimen menunjukkan bahwa asymp.sig. (2-tailed) sebesar 0,026 0,05, maka Ha (Hipotesis alternatif) diterima dan $\mathrm{Ho}$ (Hipotesis nol) ditolak. Dengan kata lain, melalui pengujian pada kelompok eksperimen (kelompok yang diintervensi dengan model konseling kelompok) adalah mampu meningkatkan self esteem siswa Sekolah Menengah Atas. Hasil uji wilcoxon pada kelompok kontrol menunjukkan bahwa asymp.sig. (2-tailed) sebesar 1,000 > 0,05, maka Ha (Hipotesis alternatif) ditolak dan Ho (Hipotesis nol) diterima. Dengan kata lain, melalui pengujian pada kelompok kontrol (kelompok yang tidak diintervensi dengan model konseling kelompok) adalah tidak mampu meningkatkan self esteem siswa Sekolah Menengah Atas.

Hasil studi yang dilakukan oleh Wilding and Milne (2013) menunjukkan bahwa cognitive behavioral therapy dapat mengoptimalkan self esteem yang rendah, di mana menekankan tentang bagaimana seseorang memandang apa yang terjadi di sekeliling dan menginterpretasikan kemampuan untuk menghadapi suatu kondisi. Individu ditingkatkan kesadaran pemikiran disfungsionalnya sehingga dapat ditantang dan diubah menjadi lebih akurat, adaptif dan realistis melalui pendekatan cognitive behavioral therapy (Beck dalam Binder, 2000). Pemikiran disfungsional diyakini dapat mempengaruhi perasaan bahagia dan keya- kinan dalam berperilaku untuk menghadapi tantangan di masa depan.

Menurut Dattilio (Corey, 2009; Foreman \& Pollard, 2011), cognitive behavioral therapy merupakan peleburan dua prinsip dan metode dalam pendekatan, yaitu kognitif dan perilaku. Cognitive behavioral therapy memandang pemikiran individu berpengaruh pada perasaan dan perilakunya (Hamdan, 2008; Beck, 2011). Penelitian Hussin dkk., (2014) yang menyatakan bahwa intervensi melalui Standart-CBT dan Brief-CBT menunjukkan bahwa dapat meningkatkan self esteem pengguna narkoba. Penelitian McManus dkk. (2009) dimana menyatakan bahwa pasien dengan gangguan kejiwaan yang disebabkan oleh selfesteem yang rendah, telah diberikan intervensi cognitive behavioral therapy. Hasilnya, pasien tersebut tidak kembali lagi untuk memeriksakan diri karena telah sembuh dari gangguan kejiwaan.

Pendekatan CBT yang digunakan dengan teknik cognitive restructuring untuk mengintervensi self esteem remaja. Beberapa penelitian komparasi yang menunjukkan bahwa integrasi spiritualitas ke dalam pendekatan CBT adalah lebih efektif dibandingkan dengan pendekatan CBT yang konvensional (Koenig dkk., 2015; Berk dkk., 2015) pada sasaran yang memiliki nilai spiritualitasnya tinggi. Selain itu, terdapat penelitian CBT yang diintegrasikan dengan keyakinan spiritualitas efektif diimplementasikan untuk penderita depresi dengan penyakit medis yang kronis (Pearce dkk. 2015). Jika dikaji lebih mendalam, self esteem merupakan akar dari aturan Islam (Motahhari dalam Joshanloo \& Daemi, 2014).

Jika dikaji lebih mendalam, spiritualitas merupakan bagian integral dan penting dalam kehidupan banyak orang. Telah ada ledakan studi baru dan penelitian di bidang ini (yang dimaksud adalah bidang integrasi spiritualitas dalam praktik konseling). Perihal spiritualitas, spiritualitas dianggap sebagai salah satu dari empat komponen dari keseluruhan kesejahteraan individu.

Penerapan integrasi spiritualitas ke dalam CBT, memerlukan teknik yang tepat untuk meningkatkan self esteem. Salah satu teknik yang paling diandalkan CBT adalah cognitive restructuring (Freeman, 2005). Hal yang sama dikemukakan oleh Lochman (1992) bahwa cognitive restructuring dapat meningkatkan self esteem pada individu. Seba- 
gai pendukung, telah ada penelitian di Indonesia bahwa teknik cognitive restructuring efektif digunakan untuk meningkatkan self esteem siswa (Mujiyati, 2013; Nugroho \& Titin, 2015). Intervensi kognitif dengan teknik cognitive restructuring tidak konsisten memberikan nilai tambah bagi intervensi perilaku.

Jika ditelaah lebih jauh, cognitive restructuring merupakan strategi yang menantang keyakinan dan pemikiran. Cognitive retsructuring ini ditelaah dari sisi spiritualitas (keyakinan Islam) juga menunjukkan keefektifannya dalam mengatasi gangguan kesehatan mental masyarakat muslim di Amerika (Hamdan, 2008). Terkait unsur spiritualitas (yang merujuk pada keyakinan agama islam) yang digali pada teknik konseling ini didasarkan pada sejarah islam yang dimiliki oleh kawasan Semarang. Semarang merupakan kawasan yang kental dengan nilai-nilai islam di mana Laksamana Cheng Ho pernah menyebarkan agama islam di daerah Semarang. Selain itu, kerajaan-kerajaan yang berada di Semarang didominasi oleh kerajaan Islam. Bahkan, Sultan Hadiwijaya menetapkan tanggal 2 Mei 1547 sebagai hari jadi Kota Semarang setelah berkonsultasi dengan Sunan Kalijaga yang bertepatan dengan peringatan Maulid Nabi Muhammad SAW.

Jika ditelaah pada perspektif yang lain, spiritualitas tidak dapat dipisahkan dengan praktik konseling. Pernyataan tersebut didasarkan pada hasil penelitian yang dilakukan oleh Rye\&Pargament (Pargament, 2007). Selain itu, terdapat alasan yang diungkapkan oleh Pargament (2007) tentang rasionalisasi integrasi spiritualitas ke dalam terapi, yaitu: (1) spiritualitas adalah bagian yang alami dan normal dalam kehidupan sehari-hari; (2) spiritualitas merupakan fakta dari terapi; (3) posisi manusia yang selalu berada pada perpindahan dari teori dan praktik; dan (4) spiritualitas berkontribusi dalam menjelaskan lebih detail tentang kekuatan dan kelemahan manusia.

\section{SIMPULAN}

Berdasarkan deskripsi dan hasil analisa data serta pembahasan hasil penelitian, maka dapat dikemukakan simpulan dan saran. Simpulan dari hasil penelitian ini spirituality dapat diintegrasikan ke dalam teknik konseling, yaitu cognitive restructuring dan dapat meningkatkan self esteem siswa SMA Negeri di Kota Semarang.
Hasil penelitian ini dapat dijadikan salah satu rujukan bagi guru BK (konselor) dalam meningkatkan self esteem siswa dan penelitian ini hanya terbatas pada wilayah di Kota Semarang dengan sasaran siswa SMA Negeri, sehingga diperlukan penelitian lanjutan untuk mengimplementasikan teknik ini pada wilayah yang berbeda atau lebih luas.

\section{REFERENSI}

Aunillah, F. \& Maria, G. A. (2015). Program Pengembangan Keterampilan Resiliensi untuk Meningkatkan Self Esteem pada Remaja. Gadjah Mada Journal of Professional Psychology, 1, 48-63.

Basaran, Z. (2016). The Effect of Recreational Activities on the self esteem and Loneliness Level of the Prisoners as an Alternative Education. Universal Journal of Educational Research, 4(5), 1080-1088.

Beck, J. S. (2011). Cognitive Therapy, Basics and Beyond. New York: The Guilford Press.

Berk, Lee S. dkk. (2015). Effects of Religious vs. Conventional Cognitive-Behavioral Therapy on Inflammatory Markers and Stress Hormones in Major Depression and Chronic Medical Illness: A Randomized Clinical Trial. Open Journal of Psychiatry, 5, 238-259.

Coopersmith, Stanley. (1967). The Antecedents of self esteem. San Francisco: W. H. Freeman and Company.

Corey, Gerald. 2012. Theory and Practice of Group Counseling (eighth edition). United States of America: Brooks/Cole.

Erol, Ruth Yasemin and Ulrich Orth. (2011). self esteem Development From Age 14 to 30 years: A Longitudinal Study. Journal of Personality and Social Psychology, 101(3), 607-619.

Fanaj, N., Melonashi, E., and Shkembi, F. (2014). self esteem and Hopelessness As Predictors of Emotional Difficulties: A Cross-Sectional Study Among Adolescents in Kosovo. Journal of Social and Behavioral Sciences, 165, 222-233.

Freeman, A. (2005). Encyclopedia of Cognitive Behavior Therapy. USA: Springer Science-Business Media, Inc.

Foreman, E. I., and Pollard, C. (2011). CBT: A Practical Guide. London: Icon Books Ltd.

Gladding, Samuel T. 2012. Konseling: Profesi yang 
Menyeluruh (Edisi Keenam). Terjemahan oleh Winarno dan Lilian Yuwowo. Jakarta: PT. Indeks. Hamdan, Aisha. (2008). Cognitive Restructuring: An Islamic Perspective. Journal of Muslim Mental Health, 3, 99-116.

Hussin, H., Alias, N. S. B., Othman, M. H., and Razak, N. A. (2014). The Effect of Cognitive Behavioural Therapy Group Intervention on self esteem Among Drug Users Based on Age, Journal of Asian Scientific Research, 4(11), 618-630

Joshanloo, Mohsen and Daemi, F. (2014). self esteem Mediates The Relationship between Spirituality and Subjective Well-Being in Iran. International Journal of Psychology, 1-6.

Koenig dkk. (2015). Religous vs Conventional Cognitive Behavioral Therapy for Major Depression in Persons with Chronic Medical Illness: A Pilot Randomized Trial. The Journal of Nervous and Mental Disease. 203(4), 243-251.

Leong, Frederick T.L. 2008. Encyclopedia of Conseling. The United States of America: SAGE Publications, Inc.

Lines, Dennis. 2006. Spirituality in Counseling and Psychotherapy. California: SAGE Publication

Lochman, M.M. (1992). Cognitive-Behavioral Treatment of Borderline Personality Disorder. New York: Guillford

McManus dkk. (2009). Cognitive Behavior Therapy for Low self esteem: A Case Example. Cognitive Behavioral Practic Journale, 1-10.

Mujiyati. (2013). Efektivitas Teknik Restrukturisasi Kognitif untuk Meningkatkan self esteem Siswa. Bandung: Prodi BK UPI tidak diterbitkan

Nugroho, Galih Jalu Dwi dan Titin I. P. (2015). Penerapan Konseling Kelompok Cognitive Restructuring untuk Mengurangi Rasa Rendah Diri Siswa Kelas VIII B MTs Raden Paku Wringinanom Gresik. Jurnal Unesa, 2(1).

Pargament, Kenneth I. (2007). Spiritually Integrated Psychotherapy: Understanding and Addressing the Sacred. New York: The Guilford Press

Pearce, M. J., Koenig, H. G., Nelson, B., Shaw, S. F., Cohen, H. J., and King, M. B. (2015). Religously Integrated Cognitive Behavioral Therapy: A New Method of Treatment for Major Depression in Patients with Chronic Medical Illness. Journal of HHS Public Access, 52 (1), 56-66.
Puswanti, (2014). Upaya Mereduksi Prokrastinasi Akademik Melalui Konseling Kelompok dengan Pendekatan Behavioristik Pada Siswa SMK. PSIKOPEDAGOGIA Jurnal Bimbingan dan Konseling. 3(1), 11-19

Khasanah, P. (2014). Meningkatkan Kemampuan Manajemen Konflik Melalui Konseling Kelompok. PSIKOPEDAGOGIA Jurnal Bimbingan dan Konseling. 3(2), 67-77.

Plumb, Alison M. (2011). Spirituality and Counseling: Are Counselors Prepared to Integrated Religion and Spirituality into Therapeutic Work with Clients?. Canadian Journal of Counseling and Psychoterapy, 45 (1), 1-16.

Santrock. (2007). Life Span Development: Perkembangan Masa Hidup. Terjemahan oleh Achmad Chussairi. Jakarta: Gramedia.

Salkind, Neil J. (2006). Encyclopedia of Human Development. The United States of America: SAGE Publications, Inc.

Srivastava \& Joshi, Rekha \& Joshi, Shobhna. (2014). Relationship between Self-Concept and self esteem in Adolescent. International Journal of Advanced Research, 2(2), 36-43.

Wibowo, Mungin Eddy. (2005). Konseling Kelompok Perkembangan. Semarang: Unnes Press.

Wilding, Christine and Aileen Milne. (2013). Cognitive Behavioral Therapy. Terjemahan oleh Ahmad Fuandy. Jakarta: PT. Indeks

Yusuf, Lukman dan Chandra Bagus R. (2012). Harga Diri pada Remaja Menengah Putri di SMA Negeri 15 Kota Semarang. Jurnal Nursing Studies, 1(1), 225 230. 